\title{
BLOCKCHAIN IN CONSTRUCTION LOGISTICS: STATE-OF-ART, CONSTRUCTABILITY, AND THE ADVENT OF A NEW DIGITAL BUSINESS MODEL IN SWEDEN
}

\author{
Dimosthenis Kifokeris, and Christian Koch \\ Chalmers University of Technology, Gothenburg, Sweden
}

\begin{abstract}
Research on blockchain technology implementation within civil engineering is quickly emerging. The use of blockchain for the integration of the material and economic flows within construction supply chain - thus creating a new digital business model for the related actors - to enhance a construction project's production, logistics management, and constructability, has been only scarcely investigated. In this paper, this shortage is documented through a comprehensive literature review. Then, the potential of Swedish independent third-party logistics consultants as a fertile ground for such a digital business model, is examined. Finally, conclusions about the pursuance of this potential paradigm shift are drawn.
\end{abstract}

\section{Introduction}

There are several approaches to define and frame the field of blockchain technology, after its first emergence in Nakamoto's (2008) seminal work (Konstantinidis et al., 2018). Among others, there has been focus on understanding it as a disruptive technology that prepares a technological ecosystem for the upcoming emergence of the Internet of Things (IoT) (Woodhead et al., 2018), and its framing as a means of performance measurement within processes containing consecutive and/or simultaneous steps (Kuhi et al., 2018). However, a generally acceptable approach underlying individual framings such as the above, defines blockchain as a peerto-peer system of transacting values (in the form of a shared, decentralized and open ledger replicated across nodes), without the need of trusted third-party intermediaries in between to verify, secure, and settle the transactions (Dannen, 2017; O'Leary, 2017; Singhal et al., 2018). Blockchain acts as a layer on top of the Internet, which can co-exist with other Internet technologies, and its ledger databases are append-only; they cannot be altered, and every entry is permanent, with the new ones being reflected on all database copies hosted in different nodes (Singhal et al., 2018). The three major functional components of blockchain are game theory (as its mathematical basis), cryptography (as its main operational framework), and computer science (as the field of its realization) (Belle, 2017; Singhal et al., 2018).

Within the construction sector, and following earlier considerations on the transparency of information access and management in construction projects (Craig \&
Sommerville, 2006), and the improvement of the contractual and procurement procedures (Eriksson \& Lind, 2016), blockchain has been researched both in terms of theoretical understanding and practical implementation (Barima, 2017; Belle, 2017; Turk \& Clink, 2017; Wang et al., 2017; Kamenetskii \& Yas'kova, 2018; Klyukin et al., 2018; Li et al., 2018,2019a; Navadkar et al., 2018). However, the use of blockchain for the integration of the material and economic flows within the production process of a construction project has yet to be investigated.

Such an integration could formulate a new digital business model - namely, the organizational background and processes to create, deliver and capture value (Osterwalder \& Pigneur, 2010; Konstantinidis et al., 2018; Momo et al., 2018), but in a digitalized context. This is culminated through the "value proposition", namely the creation of value for the client who is willing to pay for it, thus converting it into turnover and profit for the firm (Mangematin \& Baden-Fuller, 2015; Andreini \& Bettinelli, 2017). Such a new digital business model could integrate the attributes of the operational canvas by Osterwalder and Pigneur (2010): proposing and creating value for the key stakeholders and clients, monitoring key activities, key resources, stakeholder relationships and flow channels, understanding the related cost structure, and facilitating the revenue streams. In this paper, the absence of such a digital business model within the civil engineering research on blockchain technology, is highlighted; its problem-solving capabilities, uses, faced challenges, and limitations - also considering its security (Kareem et al., 2018) and its relation to constructability (Kifokeris \& Xenidis, 2017) - will be noted; and the fertile ground for its implementation within the growing ecosystem of independent third-party logistics consultant firms operating in the Swedish construction sector, will be examined.

In the second section of the paper, the literature review about the state-of-art research on blockchain implementation in construction is presented, and the research and implementation gaps are showcased. In the third section of this paper, certain particularities in the Swedish construction sector are shown; then, they are tied with the proposition of the new general digital business model. Finally, in the fourth section, conclusions about the proposed paradigm shift and the advent of the new digital business model, are drawn. 


\section{Blockchain technology in the construction sector}

Research on the development and implementation of blockchain technology within the construction sector is relatively new (Penzes, 2018), and with related application systems and developed solutions generally not being yet technologically and commercially mature (Gerber \& Nguyen, 2019; Nguyen et al. 2019). The research efforts are mainly discretized into two categories: holistic research on the understanding and implementation of blockchain, and dedicated research on the targeted integration of blockchain with distinct fields within the lifecycle of a construction project.

The holistic approach features the following research dimensions:

- Lateral integration of blockchain within existing processes and frameworks in the construction project lifecycle, namely within procurement (Barima, 2017; Wang et al., 2017; Kamenetskii \& Yas'kova, 2018; Navadkar et al., 2018), process re-engineering through digitalization (Belle, 2017; Polim et al., 2017; Coyne \& Onabolu, 2018; Gausdal et al., 2018; Klyukin et al., 2018), setting the goals of strategic innovation (Graglia and Mellon, 2018), knowledge management (Piraquive et al., 2017), and logistics and supply chain management (Wang et al., 2017; Dobrovnik et al. 2018; Rubio et al. 2018). The efforts following this dimension mainly address the problem of process automation and optimization, as well as the effect of mitigating the human intervention in such processes.

- Proposal of new integrated frameworks using blockchain, regarding the technical, social and political dimensions in addressing the problem of the relative technological implementation (Li et al., 2018,2019a)

The dedicated approach features the following research dimensions:

- Implementation of smart contracts (namely, computer protocols that facilitate, verify, or enforce the negotiation or performance of a contract, and/or obviate the need for a contractual clause) for all transactions (Cuccuru, 2017; Mason, 2017; Lamb, 2018; Mason \& Escott, 2018). The efforts following this dimension mainly address the problem of process automation and optimization as well, but in dedicated fields rather than at a high-end systemic level.

- Interconnection of blockchain with IoT, to enhance construction productivity and performance (Heiskanen, 2017; Kochovski \& Stankovski, 2018).

- Interconnection of blockchain with Building Information Modelling (BIM), and especially for facilitating trust among stakeholders (Mathews et al., 2017), resolving data issues like confidentiality, provenance tracking, disintermediation, nonrepudiation, multiparty aggregation, traceability, interorganizational record keeping, change tracing, and data ownership (Turk \& Klinc, 2017), and using IoT as a data source for BIM (Arthur et al., 2018). There has even been negative critique on such an interconnection, as Ghaffarianhoseini et al. (2017) state that blockchain cannot be integrated with BIM in a way that creates additional value but would rather be more useful just as a tool for document handling, auto-invoicing and automated control.

- Interconnection of blockchain with Computer Aided Design (CAD), for the optimization of the issue of digital design distribution and validation (Dounas \& Lombardi, 2018).

- Interconnection of blockchain with radio frequency identification (RFID) technologies for logistics and site management (Lanko et al., 2018), to address the problem of streamlining the construction supply chain.

In all the above, and especially regarding construction logistics and supply chain management (Wang et al., 2017; Dobrovnik et al. 2018; Lanko et al., 2018; Rubio et al. 2018), there has not been an investigation on the capabilities of blockchain for the integration of the respective material and the economic flows. Considerations on pursuing this integration have been already been noted in the relative research (Love et al. 2004; Koçtaş \& Tek 2013; Li et al., 2017). The consensus was that such an integration could:

- Facilitate a holistic overview of the full production of the construction project.

- Foster trust, transparency and traceability in transactions and flows.

- Enhance the quality management of the on-site deliverables (e.g. equipment or materials).

- Aid in stakeholder collaboration through the decentralization brought about by the blockchain network.

- Create monetary and qualitative value for the stakeholders.

- Assist in the optimization of a project's constructability, namely "the optimum use of construction knowledge and experience in planning, design, procurement, and field operations to achieve overall project objectives" (Construction Industry Institute, 1986). Important constructability aspects are a holistic view on logistics, supply chain integration, and close stakeholder cooperation through trusted transactions (Kifokeris \& Xenidis, 2017), which pose direct interfaces with blockchain implementation.

The need for such an integration can also be addressed by the capabilities of blockchain technology itself, as has also been noted in related research efforts outside the field of construction (Chen et al., 2017; O'Leary, 2017; Risius \& Spohrer, 2017; Wu et al., 2017; Francisco \& Swanson, 2018; Kavassalis et al. 2018). For the conception of a new digital business model regarding the integrated blockchain implementation within the construction logistics and supply chain, the research output mentioned above (both construction-related and not) should be considered, along with:

- State-of-art developments on the understanding and implementation of blockchain technology for logistic 
and supply chain management in general (Büyüközkan \& Göçer, 2018; Chichoni \& Webb, 2018; Hofmann \& Rutschmann 2018; Hofstetter, 2018; Kim \& Laskowski, 2018; Kshetri, 2018; Mukri, 2018; Verhoeven et al., 2018). Central in these research efforts is novel "value creation" through blockchain solutions for the corresponding supply chains. Such a value can be enhanced by integrating interrelated business aspects of supply chain processes with the introduced blockchain technologies, such as the material and the economic flows.

- Insights gained from the particularized blockchainrelated research for supply chains within the manufacturing industry (Kayikci, 2018; Kremer, 2018; Mondragon et al., 2018). While Aloini et al. (2012) have noted certain differences between the manufacturing and construction supply chains (namely, dissimilar project complexity, configuration intensity, customer influence, process fragmentation, and stakeholder interconnection), these supply chains depict indeed a certain procedural similarity (Koçtaş \& Tek, 2013). The discretization of manufacturing supply chains into discernible processes and flows (Mondragon et al., 2018) can correspond to the processes and flows of construction supply chains, and thus be extrapolated accordingly (Koçtaş \& Tek, 2013). So, the advances of blockchain implementation in manufacturing, complemented by the research outcomes noted in the previous bullet, can be valuable for blockchain development within construction.

- Attention to the security issues identified for and of blockchain implementation (Khong \& Escobar, 2017; Harlev et al., 2018; Kareem et al., 2018; Sklaroff, 2018; Underwood, 2018; Veuger, 2018). The "for" issues are mainly connected to the lack of trust among stakeholders in the adoption of blockchain; the disruption brought about by blockchain can be viewed with discomfort, and extreme opinions even regard it as a fad. The "of" issues are mainly derived from the abuse of those properties that make blockchain a novel disruption technology in the first place; the node-like anonymity of the distributed network can be a driver for illicit activities, the cryptocurrencies used can cause the loss of real-value grasp, any breach in the system cryptography can lead to the immediate and unrecoverable loss of virtual funds (as opposed to the potentially retrievable flat currency funds), and the potential inflexibility of the automated processes can lead to loss rather than creation of value for the stakeholders. A new integrated digital business model for blockchain implementation in the construction supply chain and logistics should address and face those concerns.

- Emphasis on construction-specific frameworks of production and management interconnected with supply chains. Most prominent among such frameworks is constructability, which can both impact and be impacted positively by an effective supply chain with integrated flows, procedural transparency, and simultaneous early contractor involvement in the construction project lifecycle (Love et al., 1999; O'Brien, 1999; Khalfan et al., 2001; Love et al., 2004; Karim et al., 2006; Khalfan et al., 2010; Chen, 2012; Saunders et al., 2015; Kifokeris \& Xenidis, 2017). Other construction-specific aspects to be emphasized can include the implementation of lean construction principles (Koçtaş \& Tek, 2013; Santorella, 2017), component prioritization (Jiang, 2016) for economic flow optimization, and the effect of the chosen contractual strategy (e.g. design-bid-build or designand-build) (Clough et al., 2015).

- Acknowledgement of the capabilities of already developed blockchain systems - such as IBM Blockchain (Forrester Consulting, 2018) - and research on their enhancement, customization, implementation and even replacement.

Building on the above, and in considering the implementation of such a digital business model, major potential uses of blockchain in construction logistics with the aim of integrating the material and economic flows in the supply chain, can include the following:

- Deployment of a decentralized blockchain network, with the nodes corresponding to stakeholders involved in the logistics and supply chain management (e.g. clients, contractors, subcontractors, suppliers, transporters, and logistics consultants - see in the following section). This network will function as a shared, immutable ledger with historic data accessible by the stakeholders.

- Automation and direct connection of the payments to the suppliers and transporters, also with potentially using IoT. For example, data regarding the arrival and supply of materials and equipment (e.g. through sensors identifying the RFID tags of construction vehicles arriving on-site) can trigger smart contracts on the blockchain network, which will automatically support the sending of the respective payments to the relevant actors. Such payments can be realized in a form of cryptocurrency accepted by the actor, or they can be translated in fiat currencies, as per the respective crypto-system implemented in the utilized blockchain network.

- Tracking the origin of supply chain inputs (e.g. construction materials like gravel and cement) through the append-only sequences of blocks in the blockchain, and cross-checking their quality, along with the integrity and validity of the process followed by the respective subcontractors, suppliers and transporters. Any smart contract triggers related to the payment of the aforementioned actors can also include clauses considering such process-oriented cross-checks.

However, such an implementation can face significant challenges. Central among them, are the "for" and "of" security issues described above and within the respective literature (Khong \& Escobar, 2017; Harlev et al., 2018; Kareem et al., 2018; Sklaroff, 2018; Underwood, 2018; Veuger, 2018); namely, the lack of trust among stakeholders in the adoption of blockchain, discomfort in the disruption brought about by blockchain, fear of 
potential illicit activities rooted in the node-like anonymity of the distributed network, loss of real-value grasp due to the use of cryptocurrencies, immediate and unrecoverable loss of virtual funds in the case of breach in the system cryptography (however unlikely and/or extremely costly in computational means this may be), and potential inflexibility of the automated processes. In addition, blockchain is considered by some researchers as somewhat ambiguous in its claim on value creation especially for construction logistics - (e.g. in Li et al., $2019 \mathrm{~b}$ ), and as difficult to implement without the simultaneous implementation and support of other types of infrastructure as well, such as BIM and IoT (Ye et al., 2019). Finally, an always present challenge is the stimulation of the respective actors and stakeholders into adopting a new digital business model utilizing such a technology. For this, the matter of understandable, monetizable, and readily available value creation is crucial.

Coupled with the challenges are the potential limitations of such an implementation. There is currently little widespread understanding of the technology underlying blockchain within the construction sector (and especially within the field of construction logistics), making the respectively dedicated and/or knowledgeable practitioners relatively rare. Due to this limitation, even in the case of an actual investment in blockchain for construction logistics, its realization may entail the outsourcing of the development process to blockchain technicians not necessarily familiar to the particularities of construction supply chains and logistics. Furthermore, cryptocurrencies may be increasingly accepted as means for transactions, but not by all, and especially not all in the construction industry; and even if a cryptocurrency is translated into fiat currency through the relative system, it cannot be avoided in the first place, since it is essential for the function of the blockchain framework.
With this background, an early concept of such a new and generic digital business model can be presented in the canvas by Osterwalder and Pigneur (2010), as in Figure 1 (see next page). It should be underlined that within this generic model, several firm-specific business models will be needed.

\section{The case of the Swedish independent third- party logistics consultant firms}

Sweden is experiencing urbanization, as is the rest of Europe. This intensified activity and its associated complex processes, may result in issues such as delayed deliveries, complicated supply chain coordination, and low productivity and efficiency (Dubois et al., 2017). To ameliorate such issues and facilitate all associated logistics services, one state-of-art business practice is the employment of independent third-party logistics consultant firms, which assist in coordinating and handling complex, recurrent and conflicting flows consisting of deliveries of materials, arrival of incoming goods, and other sub-systems. These firms are often small organizations; they embody a business model for improved construction logistics, strengthening the coordination across the supply chain by connecting the client, the material and equipment transport companies, the contractors, and the subcontractors. The most prominent among these firms are featured in Table 1 (see next page), with this list being based on the authors' targeted communication with firm representatives, the firms' websites, and related literature (Gustavsson, 2018). By configuring their business practice in the way described above, these firms are given a central role within the development of a construction project.

However, there is no established approach and level of digitalization in the coordination process they carry out in some cases, it is facilitated by the third-party logistics firms taking a role as collaboration and process consultants, while in others it is supported by IT systems,

\begin{tabular}{|c|c|c|c|c|}
\hline$\underline{\text { Key }}$ & & \multirow{9}{*}{$\begin{array}{l}\text { Value proposition } \\
\text { The logistics processes will be } \\
\text { quicker, more efficient, more } \\
\text { comprehensive, and more } \\
\text { automated. The transactions and } \\
\text { payments will be more secure, } \\
\text { instant, decentralized, correct, } \\
\text { and transparent. The optimization } \\
\text { of the integrated flows will allow } \\
\text { less rework, better change } \\
\text { management, and optimized site } \\
\text { operations. The role of } \\
\text { economically dependent } \\
\text { stakeholders (e.g. subcontractors) } \\
\text { will be enhanced in a lateral } \\
\text { manner. }\end{array}$} & \multirow{3}{*}{\begin{tabular}{|l|} 
Customer \\
relationships \\
Close collaboration \\
Dynamic transactions \\
Peer-to-peer \\
\end{tabular}} & \multirow{2}{*}{$\frac{\text { Customer }}{\text { segments }}$} \\
\hline & & & & \\
\hline $\begin{array}{l}\text { IT infrastru } \\
\text { specialists } \\
\text { Clients }\end{array}$ & $\begin{array}{l}\text { proje } \\
\text { produ } \\
\text { mana }\end{array}$ & & & \multirow{5}{*}{$\begin{array}{l}\text { As created by the } \\
\text { segmentation of } \\
\text { the process } \\
\text { through the } \\
\text { implementation } \\
\text { of disruptive } \\
\text { blockchain } \\
\text { technology }\end{array}$} \\
\hline & & & & \\
\hline Subc & Hun & & & \\
\hline & & & & \\
\hline & & & & \\
\hline \multirow{2}{*}{\multicolumn{2}{|c|}{$\begin{array}{l}\text { Cost structure } \\
\text { Cost paid by the client and/or main } \\
\text { contractor } \\
\text { Included in the fees of the logistics } \\
\text { consultants and/or IT specialists }\end{array}$}} & & \multicolumn{2}{|l|}{$\underline{\text { Revenue streams }}$} \\
\hline & & & \multicolumn{2}{|c|}{$\begin{array}{l}\text { As created by the operation of the nodes } \\
\text { in the blockchain } \\
\text { Decentralized, secure, transparent, and } \\
\text { resulting through instant transactions }\end{array}$} \\
\hline
\end{tabular}

Figure 1: Canvas of an integrated blockchain solution for construction supply chain and logistics 
which are generally fragmented and non-integrated. These approaches do not have to be mutually exclusive, and in some cases, they are all used to some extent. They are summarily noted in the "Approach" column in Table 1, where it is hinted that some firms may still deploy a more traditional business model using established methods and tools (e.g. Prolog), while others mostly deploy a digital business model involving advanced technologies such as planning software and tracking systems (e.g. LogTrade,
Myloc). Nonetheless, all approaches involve collaboration and interaction with the on-site contributing parties and key suppliers; this is an important aspect to the "value proposition" of the respective business models (Mangematin \& Baden-Fuller, 2015). In a broader perspective, other adjacent players can and will influence the collaboration on building logistics in Sweden. The equipment supplier Ramirent, for example, presents an approach to digital

Table 1: Prominent third-party logistics consultant firms within the Swedish construction sector

\begin{tabular}{|c|c|c|c|c|c|c|}
\hline Name & $\begin{array}{c}\text { Turnover } \\
(2017-8)\end{array}$ & $\begin{array}{c}\text { Staff } \\
\text { no. }\end{array}$ & Industry & Main clients & Approach & $\begin{array}{c}\text { Digital } \\
\text { solution? }\end{array}$ \\
\hline LogTrade & $\begin{array}{c}\approx 2.328 \mathrm{M} \\
€\end{array}$ & 9 & $\begin{array}{l}\text { Construction, } \\
\text { manufacturing, } \\
\text { retail, transportation }\end{array}$ & $\begin{array}{l}\text { Contractors, suppliers, } \\
\text { distributors, retailers, } \\
\text { transporters }\end{array}$ & $\begin{array}{l}\text { Digitalization } \\
\text { /automation }\end{array}$ & $\begin{array}{l}\text { Yes, in- } \\
\text { house }\end{array}$ \\
\hline Myloc & $\begin{array}{c}\approx 1.483 \mathrm{M} \\
€\end{array}$ & 8 & $\begin{array}{l}\text { Construction, real } \\
\text { estate, inventories, } \\
\text { manufacturing }\end{array}$ & $\begin{array}{l}\text { Contractors, suppliers, } \\
\text { distributors, } \\
\text { manufacturers }\end{array}$ & $\begin{array}{l}\text { Digitalization } \\
\text { /automation }\end{array}$ & $\begin{array}{l}\text { Yes, in- } \\
\text { house }\end{array}$ \\
\hline $\begin{array}{c}\text { Prolog } \\
\text { Bygglogistik }\end{array}$ & $\begin{array}{c}\approx 1.905 \mathrm{M} \\
€\end{array}$ & 22 & $\begin{array}{l}\text { Construction, real } \\
\text { estate }\end{array}$ & $\begin{array}{l}\text { Contractors, suppliers, } \\
\text { distributors, } \\
\text { transporters }\end{array}$ & $\begin{array}{l}\text { Facilitation/ } \\
\text { digitalization/ } \\
\text { automation }\end{array}$ & $\begin{array}{l}\text { Yes, with } \\
\text { external } \\
\text { partner }\end{array}$ \\
\hline Servistik & $\begin{array}{c}\approx 2.749 \mathrm{M} \\
€\end{array}$ & 20 & $\begin{array}{l}\text { Construction, } \\
\text { manufacturing, } \\
\text { waste management }\end{array}$ & $\begin{array}{l}\text { Contractors, suppliers, } \\
\text { distributors, } \\
\text { manufacturers, } \\
\text { transporters }\end{array}$ & $\begin{array}{l}\text { Facilitation/ } \\
\text { digitalization/ } \\
\text { automation }\end{array}$ & $\begin{array}{l}\text { Yes, in- } \\
\text { house }\end{array}$ \\
\hline $\begin{array}{c}\text { Svenskt } \\
\text { Byggdialog }\end{array}$ & $\begin{array}{c}\approx 100.871 \\
\mathrm{M} €\end{array}$ & 138 & $\begin{array}{l}\text { Construction, real } \\
\text { estate }\end{array}$ & $\begin{array}{l}\text { Contractors, suppliers, } \\
\text { manufacturers }\end{array}$ & $\begin{array}{l}\text { Facilitation/ } \\
\text { digitalization/ } \\
\text { automation }\end{array}$ & $\begin{array}{l}\text { Yes, in- } \\
\text { house }\end{array}$ \\
\hline $\begin{array}{c}\text { Svenskt } \\
\text { Bygglogistik }\end{array}$ & $\begin{array}{c}\approx 4.167 \mathrm{M} \\
€\end{array}$ & 25 & $\begin{array}{l}\text { Construction, real } \\
\text { estate, transportation }\end{array}$ & $\begin{array}{l}\text { Contractors, suppliers, } \\
\text { distributors, } \\
\text { transporters }\end{array}$ & $\begin{array}{l}\text { Facilitation/ } \\
\text { digitalization/ } \\
\text { automation }\end{array}$ & $\begin{array}{l}\text { Yes, in- } \\
\text { house }\end{array}$ \\
\hline $\begin{array}{c}\text { FM } \\
\text { Management }\end{array}$ & $\begin{array}{c}\approx 2.337 \mathrm{M} \\
€\end{array}$ & 8 & $\begin{array}{l}\text { Construction, real } \\
\text { estate, transportation }\end{array}$ & $\begin{array}{l}\text { Contractors, suppliers, } \\
\text { distributors, } \\
\text { transporters }\end{array}$ & $\begin{array}{l}\text { Facilitation/ } \\
\text { digitalization/ } \\
\text { automation }\end{array}$ & $\begin{array}{l}\text { Yes, with } \\
\text { external } \\
\text { partner }\end{array}$ \\
\hline
\end{tabular}

logistics solutions echoing the business model implemented by other Swedish firms offering miscellaneous construction services, such as, Buildsafe, Loop Rocks, Ene Golv, and Edvirt. Moreover, the continued dominance of contractor-driven buildingLogistics is also developing and should be researched; Veidekke Sweden, for example, has acquired and uses in-house the services of a dedicated and previously autonomous logistics company. Finally, bestpractices and lessons-learned from the business models of global logistics firms operating in Sweden, such as DB Schenker, DSV, and UPS, should be studied - currently not allowed in the short space of this conference paper.

In such collaborative business models, their digitalization (or the enhancement of their already digitalized solutions) with the use of blockchain can optimize their efficiency and lower their respective costs (McKinsey Global Institute, 2017). The properties of blockchain align with the need to view digital business models in an interorganizational manner and not only as a single company effort (Vendrell-Herrero et al., 2018) - something offered when partnering with the third-party logistics consultant firms. Digital business models involve the alliance of incumbent product-oriented firms with newcomers having digital capabilities, as a way of assuring agility and overcoming inertia in existing supply chains (VendrellHerrero et al., 2018).

Apart from the collaborative aspect, in developing digital business models for construction supply chains and logistics, an integrated and agile approach is needed (Thunberg \& Fredriksson, 2018). In such an approach, the planning of on-site space utilization for provisional storage can be continuous, substituting the previous, more static "Area Disposition Plan" (APD) approaches. It is recurrent to mention APD as dynamic, but this rarely implies continuous integration between logistics planning and material registration, placement and installation. Such a digital approach could be integrated with the flow control system and would also involve blockchain in handling the economic flow along the physical flow (O'Leary 2017).

The employment of third-party logistics consultants can bring about all such sought collaborative, integrated and agile aspects. However, issues of delivery failure, unprecise data, delays in time, and inefficient flows and data transfers between systems, still occur, preventing the 
efficiency optimization of construction supply chains and logistics - especially in large construction sites. On-site physical placement is rarely tied to any implemented digital solutions. Moreover, these firms are burdened with justifying the value-for-money for their logistics services fees - the disintegration between the material and the economic flows is evident in the decoupling between the payments for the deliveries and transportation services, and for the logistics solution.

Thus, it can be derived that the third-party logistics consultants within the Swedish construction sector both:

- Present a fertile ground for the implementation of a dedicated digital business (as a particularization of the conceptual and generic digital business model described earlier) featuring a blockchain solution that integrates the material and economic flows within the construction supply chain and logistics, since the firms display the collaborative and integrating aspects aligning with such an implementation, and

- Need such a digital business model. Even in the case of more digitally advanced firms, on-site issues of disintegration, and matters of value-for-money justification due to the decoupling of the material and economic flows, have still to be tackled.

The "value proposition" in this case, and following the early conceptual business plan in Figure 1, would be a holistic, transparent, automated and fully integrated solution for the realization of the construction supply chain and logistics processes in an unhindered way. This could facilitate the generation of additional value for the "customers" - owners, contractors and subcontractors which could then turn to profit.

\section{Conclusions}

Blockchain is an emerging technology with disruptive potential, acting as a peer-to-peer system of transacting values (in the form of a shared, decentralized and open ledger replicated across nodes), with a reduced need of trusted third-party intermediaries in between to verify, secure, and settle the transactions.

Within the construction sector, the implementation of blockchain has been investigated both in a general and in a dedicated manner. However, there has been little research on a blockchain solution integrating the material and economic flows within the construction supply chains and logistics. Such an integration could holistically facilitate the full production of a construction project, foster trust, transparency and traceability in transactions and flows, enhance the quality management of deliverables, aid in stakeholder collaboration, and create monetary and qualitative value. This integration can ultimately be realized into a digital business model for the third-party building logistics consultants that draws from knowledge generated from the implementation of integrated blockchain solutions in other industries, and incorporates construction-specific aspects, such as constructability, lean construction and the effects of the elected contractual strategy. However, the adoption of such a digital business model can face challenges, such as trust and security issues, and also be demarcated by limitations, such as the relatively sparse knowledge of blockchain fundamentals within the construction sector.

The Swedish independent third-party logistics consultant firms reveal, through their distinctive characteristics and operational processes, both a capability and a need for such an integrated blockchain solution. Thus, problems of on-site process disintegration, and justification of valuefor-money, could be effectively mitigated.

The robust conceptualization and development of such a digital business models cannot be disintegrated from the operational processes and business models of the stakeholders collaborating with the independent thirdparty logistics consultant firms in Sweden. The interfaces with material and equipment rental/supplying firms, companies offering miscellaneous construction services, and global logistics firms should be investigated. Moreover, the dominant contractor-driven building logistics practice should be researched, as large contractors are currently developing their capabilities.

As future work, not only the research on the business models and processes of the aforementioned actors will follow, but also the identification, for each stakeholder, of the value creation through the implementation of an integrated blockchain solution, will take place. Moreover, the robustification and particularization of the proposed early conceptual and generic digital business model, with a central interest in creating a dedicated digital business model for the independent third-party logistics consultants in Sweden, will be pursued. In addition, the blockchain technology infrastructure itself, including the integration of flows, the distributed network, the smart contracts, the on-site triggers, and the end-user application, will be developed into a prototype. Finally, this prototype will be tested and verified in the case of a construction site, and with the attendance of the actors respectively represented by the relative nodes in the distributed network.

\section{References}

Aloini A., Dulmin R., Mininno V. \& Ponticelli S. (2012) A conceptual model for construction supply chain management implementation. In: Proceedings of the $28^{\text {th }}$ Annual ARCOM Conference. Edinburgh, UK.

Andreini, D. \& Bettinelli, C. (2017) Business Model Innovation: From Systematic Literature Review to Future Research Directions. Springer Nature. Cham, Switzerland.

Arthur, S., Li, H. \& Lark, R. (2018) The Emulation and Simulation of Internet of Things Devices for Building Information Modelling (BIM). In: EG-ICE 2018, LNCS 10864. Springer International Publishing.

Barima, O. (2017) Leveraging the blockchain technology to improve construction value delivery: the opportunities, benefits and challenges. In: Construction Projects: Improvement Strategies, Quality Management and Potential Challenges. Nova Publishers, NY, USA.

Belle, I. (2017) The architecture, engineering and 
construction industry and blockchain technology. In: Digital Culture - Proceedings of the 2017 National Conference on Digital Technologies in Architectural Education and DADA 2017 International Conference on Digital Architecture. Nanjing, China.

Büyüközkan, G. \& Göçer, F. (2018) Digital Supply Chain: Literature review and a proposed framework for future research. Computers in Industry, 97, pp. 157-177.

Chen, H.L. (2012) Empirical behavioral analysis of project contractors' supply-chain payment terms. Supply Chain Management: An International Journal, 17(3), pp. 277-289.

Chen, S., Shi, R., Ren, Z., Yan, J., Shi, Y. \& Zhang, J. (2017) A Blockchain-based Supply Chain Quality Management Framework. In: Proceedings of The Fourteenth IEEE International Conference on $e$ Business Engineering. Shanghai, China.

Chichoni, J. \& Webb, S. (2018) The digital global supply chain: the growing case for blockchain technology expansion within global supply chain. Honors Thesis. Brigham Young University, Provo, UT, USA.

Clough, R.H., Sears, G.A., Sears, S.K., Segner, R.O. \& Rounds, J.L. (2015) Construction contracting: A practical guide to company management ( $8^{\text {th }}$ ed.). Wiley, NY, USA.

Construction Industry Institute (1986) Constructability: A Primer. University of Texas at Austin, Austin, TX, USA.

Coyne, R. \& Onabolu, T. (2018) Blockchain for architects: challenges from the sharing economy. Architectural research Quarterly, 21(4), pp. 369-374.

Craig, N. \& Sommerville, J. (2006) Information management systems on construction projects: case reviews. Records Management Journal, 16(3), pp. 131-148.

Cuccuru, P. (2017) Beyond bitcoin: an early overview on smart contracts. International Journal of Law and Information Technology, 25(3), pp. 179-195.

Dannen, C. (2017) Introducing Ethereum and Solidity: Foundations of Cryptocurrency and Blockchain Programming for Beginners. Apress, Berkeley, CA, USA.

Dobrovnik, M., Herold, D.M., Fürst, E. \& Kummer, S. (2018) Blockchain for and in Logistics: What to Adopt and Where to Start. Logistics, 2(18), pp. 1-14.

Dounas, T. \& Lombardi, D. (2018) A CAD-Blockchain Integration Strategy for Distributed Validated Digital Design. In: eCAADe 2018: Computing for a better tomorrow. Lodz, Poland.

Dubois, A. Hulthén, K, \& Sundquist, V. (2017) Organising logistics and transport activities in construction. The International Journal of Logistics Management, 30(2), pp. 620-640.

Eriksson, P.E. \& Lind, H. (2016). Strategies for reducing moral hazard in construction procurement: a conceptual framework. Journal of Self-Governance and Management Economics, 4(1), pp. 7-33.

Forrester Consulting (2018). Emerging Technology Projection: The Total Economic Impact ${ }^{T M}$ of IBM Blockchain. Forrester Research, Inc., Cambridge, MA,
USA.

Francisco, K. \& Swanson, D. (2018) The Supply Chain Has No Clothes: Technology Adoption of Blockchain for Supply Chain Transparency. Logistics, 2(1), pp. 2$1-2-13$.

Gausdal, A.H., Czachorowski, K.V. \& Solesvik, M.Z. (2018) Applying Blockchain Technology: Evidence from Norwegian Companies. Sustainability, 10(1985), pp. 1-16.

Gerber, D., \& Nguyen, B. (2019) Blockchain technology timeline: case studies in the built environment. Arup, London, UK.

Ghaffarianhoseini, Al., Tookey, J., Ghaffarianhoseini, Am., Naismith, N., Azhar, S., Efimova, O. \& Raahemifar, K. (2017) Building Information Modelling (BIM) uptake: Clear benefits, understanding its implementation, risks and challenges. Renewable and Sustainable Energy Reviews, 75, pp. 1046-1053.

Graglia, J.M. \& Mellon, C. (2018) Blockchain and property in 2018. Innovations, 12(1/2), pp. 90-116.

Gustavsson, T.K. (2018) Liminal roles in construction project practice: exploring change through the roles of partnering manager, building logistic specialist and BIM coordinator. Construction Management and Economics, DOI: 10.1080/01446193.2018.1464197.

Harlev, M.A., Yin, H.S., Langenheldt, K.C., Mukkamala, R.R. \& Vatrapu, R. (2018) Breaking Bad: DeAnonymising Entity Types on the Bitcoin Blockchain Using Supervised Machine Learning. In: Proceedings of the $51^{\text {st }}$ Hawaii International Conference on System Sciences. Hawaii, USA.

Heiskanen, A. (2017) The technology of trust: How the Internet of Things and blockchain could usher in a new era of construction productivity. Construction Research and Innovation, 8(2), pp. 66-70.

Hofmann, E. \& Rutschmann, E. (2018) Big data analytics and demand forecasting in supply chains: a conceptual analysis. The International Journal of Logistics Management, 29(2), pp. 739-766.

Hofstetter, J.S. (2018) Extending Management Upstream in Supply Chains Beyond Direct Suppliers. IEEE Engineering Management Review, 46(1), pp. 106-116.

Jiang, L. (2016). A constructability review ontology to support automated rule leveraging building information models. Ph.D. thesis. Penn State University, PA, USA.

Kamenetskii, M.I. \& Yas'kova, N.Y. (2018) Construction and Real Estate Markets: From Crisis to Growth. Studies on Russian Economic Development, 29(1), pp. 35-40.

Kareem, A., Sulaiman, R.B. \& Farooq, M.U. (2018) Algorithms and Security Concern in Blockchain Technology: A Brief Review. Available online at the Social Science Research Network (SSRN) repository: http://dx.doi.org/10.2139/ssrn.3234933.

Karim, K., Marosszeky, M. \& Davis, S. (2006) Managing subcontractor supply chain for quality in construction. Engineering, Construction and Architectural Management, 13(1), pp. 27-42. 
Kavassalis, P., Stieber, H., Breymann, W., Saxton, K. \& Gross, F.J. (2018) An innovative RegTech approach to financial risk monitoring and supervisory reporting. The Journal of Risk Finance, 19(1) pp.39-55.

Kayikci, Y. (2018) Sustainability impact of digitization in logistics. Procedia Manufacturing, 21, pp. 782-789.

Khalfan, M.M.A., Anumba, C.J., Siemieniuch, C.E. \& Sinclair, M.A. (2001) Readiness Assessment of the construction supply chain for concurrent engineering. European Journal of Purchasing \& Supply Management, 7(2), pp. 141-153.

Khalfan, M.M.A., Kashyap, M., Li, X. \& Abbott, C. (2010) Knowledge management in construction supply chain integration. International Journal of Networking and Virtual Organizations, 7(2/3), pp. 207-221.

Khong, M. \& Escobar, M. (2017) New money: are we ready to take on the impacts of a cashless society? A fantasy pitch. Accounting and Management Information Systems, 16(4), pp. 641-647.

Kifokeris, D. \& Xenidis, Y. (2017) Constructability: Outline of Past, Present and Future Research. Journal of Construction Engineering and Management, 143(8), pp. 04017035-1 - 04017035-13.

Kim, H.M. \& Laskowski, M. (2018) Toward an ontologydriven blockchain design for supply-chain provenance. Intelligent Systems in Accounting Finance \& Management, 25, pp. 18-27.

Klyukin, A.A., Kulachkovsky, V.N., Evseev, V.N. \& Klyukina, A.I. (2018) Possibilities of New Information Technologies in the System of Urban Planning and Construction. Key Engineering Materials, 771, pp. 4955.

Kochovski, P. \& Stankovski, V. (2018) Supporting smart construction with dependable edge computing infrastructures and applications. Automation in Construction, 85, pp. 182-192.

Koçtaş, Ö. \& Tek, Ö.B. (2013). Construction supply chains: a proposal to develop a new conceptual model. In: Proceedings of the International Logistics and Supply Chain Congress 2013, Cappadocia \& Kayseri, Turkey.

Konstantinidis, I., Siaminos, G., Timplalexis, C., Zervas, P., Peristeras, V. \& Decker, S. (2018) Blockchain for Business Applications: A Systematic Literature Review. In: Business Information Systems - $21^{\text {st }}$ International Conference BIS 2018 Proceedings. Springer, Berlin, Germany.

Kremer, P.D. (2018) Design for Mass Customised Manufacturing and Assembly (DfMCMA): A New Framework for Mass Timber Construction. Mass Timber Construction Journal, 1, pp. 9-13.

Kshetri, N. (2018) Blockchain's roles in meeting key supply chain management objectives. International Journal of Information Management, 39, pp. 80-89.

Kuhi, K., Kaare, K., and Koppel, O. (2018) Ensuring performance measurement integrity in logistics using blockchain. In: 2018 IEEE International Conference on Service Operations and Logistics, and Informatics (SOLI). IEEE, Singapore.

Lamb, C. (2018) Blockchain and Smart Contracts: What the AEC sector needs to know. Report No. CDBB_REP_003, Centre for Digital Built Britain, University of Cambridge.

Lanko, A., Vatin, N. \& Kaklauskas A. (2018) Application of RFID combined with blockchain technology in logistics of construction materials. MATEC Web of Conferences, 170, 03032-1 - 03032-6.

Li, C.Z., Zhong, R.Y., Xue, F., Xu, G., Chen, K., Huang, G.G. \& Shen, G.Q. (2017) Integrating RFID and BIM technologies for mitigating risks and improving schedule performance of prefabricated house construction. Journal of Cleaner Production, 165, pp. 1048-1062.

Li, J., Greenwood, D.J. \& Kassem, M. (2018) Blockchain in the built environment: analysing current applications and developing an emergent framework. In: 2018 Creative Construction Conference Proceedings. Creative Construction Conference, Ljubljana, Slovenia.

Li, J., Greenwood, D.J. \& Kassem, M. (2019a) Blockchain in the Construction Sector: A Socio-technical Systems Framework for the Construction Industry. In: Advances in Informatics and Computing in Civil and Construction Engineering. Springer Nature, Cham, Switzerland.

Li, J., Greenwood, D.J. \& Kassem, M. (2019b) Blockchain in the built environment and construction industry: A systematic review, conceptual models and practical use cases. Automation in Construction, 102, 288-307.

Love, P.E.D., Irani, Z. \& Cheng, E.D.J. (2004) A seamless supply chain model for construction. Supply Chain Management: An International Journal, 9(1), pp. 4356.

Love, P.E.D., Li, H. \& Mandal, P. (1999). Rework: a symptom of a dysfunctional supply-chain. European Journal of Purchasing \& Supply Management, 5, pp. 111.

Mangematin, V. \& Baden-Fuller, C. (2015) Business Models and Modelling (Advances in Strategic Management, Volume 33). Emerald Group Publishing Limited, Bingley, West Yorkshire, UK.

Mason, J. (2017). Intelligent Contracts and the Construction Industry. Journal of Legal Affairs and Dispute Resolution in Engineering and Construction, 9(3), pp. 04517012-1 - 04517012-6.

Mason, J. \& Escott, H. (2018) Smart contracts in construction: Views and perceptions of stakeholders. In: Proceedings of the 2018 FIG Conference, Istanbul, Turkey.

Mathews, M., Robles, D. \& Bowe, B. (2017) BIM+Blockchain: A Solution to the Trust Problem in Collaboration? In: CITA BIM Gathering 2017, Dublin, Ireland.

McKinsey Global Institute (2017) A future that works: automation, employment and productivity. McKinsey Global Institute, NY, USA.

Momo, F.D.S., Schiavi, G.S. \& Behr, A. (2018) Business models and blockchain: what can change? In: Proceedings of the 2018 Association for Information Systems (AMCIS) Conference. Online repository. 
Mondragon, A.E.C., Mondragon, C.E.C. \& Coronado, E.S. (2018) Exploring the applicability of blockchain technology to enhance manufacturing supply chains in the composite materials industry. In: Proceedings of IEEE International Conference on Applied System Innovation 2018. IEEE Online Repository.

Mukri, B. (2018) Blockchain Technology in Supply Chain Management: A Review. International Research Journal of Engineering and Technology, 5(6), pp. 2497-2500.

Nakamoto, S. (2008) Bitcoin: A Peer-to-Peer Electronic Cash System. <https://bitcoin.org/bitcoin.pdf $>$ (Accessed 09 Nov. 2018)

Navadkar, V.H., Nighot, A. \& Wantmure, R. (2018) Overview of blockchain technology in government/public sectors. International Research Journal of Engineering and Technology, 5(6), pp. 2287-2292.

Nguyen, B., Buscher, V., Cavendish, W., Gerber, D., Leung, S., Krzyzaniak, A., Robinson, R., Burgess, J., Proctor, M., O'Grady, K., \& Flapper, T. (2019) Blockchain and the Built Environment. Arup, London, UK.

O’Brien, W. J. (1999) Construction supply-chain management: a vision for advanced coordination, costing, and control. In: NSF Berkeley-Stanford Construction Research Workshop (Vol. 6). Stanford University, CA, USA.

O'Leary, D.E. (2017). Configuring blockchain architectures for transaction information in blockchain consortiums: The case of accounting and supply chain systems. Intelligent Systems in Accounting, Finance and Management, 24(4), pp. 138-147.

Osterwalder, A. \& Pigneur, Y. (2010) Business Model Generation. John Wiley and Sons, Hoboken, NJ, USA.

Penzes, B. (2018) Blockchain technology in the construction industry: digital transformation for high productivity. Institution of Civil Engineers (ICE) Publications, London, UK.

Piraquive, F.N.D.D., Martínez, O.S., Pérez, E.V. \& Crespo, R.G. (2017) Knowledge management model for project management: KM+PMTIC. In: Construction Projects: Improvement Strategies, Quality Management and Potential Challenges. Nova Publishers, NY, USA.

Polim, R., Hu, Q. \& Kumara, S. (2017) Blockchain in megacity logistics. In: Proceedings of the 2017 Industrial and Systems Engineering Conference, Pittsburgh, Pennsylvania, USA.

Risius, M. \& Spohrer, K. (2017) A Blockchain Research Framework: What We (don't) Know, Where We Go from Here, and How We Will Get There. Business \& Information Systems Engineering, 59(6), pp. 395-409.

Rubio, M.A., Tarazona, G.M. \& Contreras, L. (2018) Big Data and Blockchain Basis for Operating a New Archetype of Supply Chain. In: DMBD 2018, LNCS 10943. Springer International Publishing AG.

Santorella, G. (2017) Lean Culture for the Construction Industry: Building Responsible and Committed Project Teams ( $2^{\text {nd }}$ ed.). Productivity Press, CRC Press, Taylor
\& Francis Group, Boca Raton, FL, USA.

Saunders, L.W., Kleiner, B.M., McCoy, A.P., Lingard, H., Mills, T., Blismas, N., \& Wakefield, R. (2015) The effect of early supplier engagement on social sustainability outcomes in project-based supply chains. Journal of Purchasing and Supply Management, 21(4), pp. 285-295.

Singhal, D., Dhameja, G., \& Panda, P.S. (2018) Beginning Blockchain: A Beginner's Guide to Building Blockchain Solutions. Apress, Springer Science+Business Media, NY, USA.

Sklaroff, J.M. (2018) Smart contracts and the cost of inflexibility. University of Pennsylvania Law Review, 166, pp. 263-303.

Thunberg, M. \& Fredriksson, A. (2018) Bringing planning back into the picture - How can supply chain planning aid in dealing with supply chain-related problems in construction? Construction Management \& Economics, 36(8), pp. 425-442.

Turk, Ž. \& Klinc, R. (2017) Potentials of Blockchain Technology for Construction Management. Procedia Engineering, 196, pp. 638-645.

Underwood, B.D. (2018) Virtual Market Integrity Initiative Report. Office of the New York State Attorney General, NY, USA.

Vendrell-Herrero, F., Parry, G., Bustinza, O. \& Gomes, E. (2018) Digital business models: Taxonomy and future research avenues. Strategic Change, 27(2), pp. 87-90.

Verhoeven, P., Sinn, F. \& Herden, T.T. (2018) Examples from Blockchain Implementations in Logistics and Supply Chain Management: Exploring the Mindful Use of a New Technology. Logistics, 2, 20-1 - 20-19.

Veuger, J. (2018) Trust in a viable real estate economy with disruption and blockchain. Facilities, 36(1/2), pp.103-120.

Wang, J., Wu, P., Wang, X. \& Shou, W. (2017) The outlook of blockchain technology for construction engineering management. Frontiers of Engineering Management, 4(1), pp. 67-75.

Woodhead, R., Stephenson, P. \& Morrey, D. (2018) Digital construction: From point solutions to IoT ecosystem. Automation in Construction, 93, pp. 35-46.

Wu, H., Li, Z., King, B., Miled, Z.B., Wassick, J. \& Tazelaar, J. (2017) A Distributed Ledger for Supply Chain Physical Distribution Visibility. Information, 8(4), pp. 137-1 - 137-18.

Ye, Z., Yin, M., Tang, L., \& Jiang, H. (2019) Cup-ofWater theory: A review on the interaction of BIM, IoT and blockchain during the whole building lifecycle. In: Proceedings of the 35th International Symposium on Automation and Robotics in Construction (ISARC 2018). Curran Associates, New York, USA. 